\title{
PROBLEMATIKA PERLINDUNGAN HAK CIPTA DI INDONESIA
}

\section{Anis Mashdurohatun}

\begin{abstract}
Development of copyrighted works as part of the intellectual property rights that stem from results of human creation gave birth to a right of the creator of the so-called copyright. Copyright inherent in the creator differs from other intellectual property rights, because the inherent consists of two types of rights, moral rights and economic rights. The problems of copyright protection in Indonesia is caused by several things including: Islamic view of Copyrights, the public's view of the Copyright, Still Lack Popularizing Copyright Act, the Purchaser is not in the questioning, and legal awareness.
\end{abstract}

Keywords: Copyright, intellectual property right

A. Pendahuluan

Perkembangan karya
cipta sebagai bagian hak
kekayaan intelektual yang
bersumber pada hasil kreasi
manusia melahirkan suatu
hak bagi si pencipta yang
disebut sebagai hak cipta
(copyright)
Damian:2004:106). Hak
Cipta yang melekat pada
pencipta berbeda dari hak
kekayaan intelektual lainnya,
karena yang melekat terdiri
dari dua jenis hak, hak moral
dan hak ekonomi. Hak moral
(moral rights) adalah hak
yang tidak akan lepas dari
pencipta untuk selama-
lamanya. Hak eksklusif ini
dimiliki oleh pencipta untuk
melarang atau mengijinkan

Perkembangan karya kekayaan intelektual yang bersumber pada hasil kreasi manusia melahirkan suatu hak bagi si pencipta yang disebut sebagai hak cipta (copyright) (Eddy Cipta yang melekat pada pencipta berbeda dari hak kekayaan intelektual lainnya, karena yang melekat terdiri dari dua jenis hak, hak moral dan hak ekonomi. Hak moral (moral rights) adalah hak yang tidak akan lepas dari dimiliki oleh pencipta untuk melakukan perubahan terhadap isi ciptaan,judul ciptaan, nama pencipta dan ciptaan itu sendiri. Hak moral ini melekat pada pencipta walaupun ciptaannya sudah beralih ke pihak lain. Hak ekonomi (economic rights) adalah hak yang dapat dipindahkan kepada pihak lain ( pihak lain yang menjadi pemegang hak cipta) dan melalui hak inilah, pencipta mendapatkan keuntungan ekonomi dari hasil ciptaannya. Hak ini meliputi hak untuk mengumumkan dan memperbanyak atau memberikan izin untuk mengumumkan atau memperbanyak ciptaan miliknya. 
Pelanggaran hak cipta dalam bidang ilmu, seni dan sastra, pada prinsipnya merupakan tindakan kriminal sebagaimana pelanggaran hak milik orang lain pada umumnya. Pembajakan terhadap hak cipta dapat merusak tatanan sosial, ekonomi dan hukum di negara kita. Karena itu tepat sekali diundangkannya Undang-Undang Republik Indonesia Nomor 19 tahun 2002 tentang Hak Cipta yang dimaksudkan untuk melindungi hak cipta dan membangkitkan semangat dan minat yang lebih besar untuk melahirkan ciptaan baru di berbagai bidang.

Namun

dalam pelaksanaan ketentuan perundangan terkait hak cipta di Indonesia masih banyak terjadi pelanggaranpelanggaran terhadap hak cipta. Berdasarkan laporan berbagai asosiasi profesi yang berkaitan erat dengan hak cipta di bidang buku dan penerbitan, musik dan lagu, film dan rekaman video, dan komputer, bahwa pelanggaran terhadap hak cipta masih tetap berlangsung; bahkan semakin meluas sehingga sudah mencapai tingkat yang membahayakan dan mengurangi kreativitas untuk mencipta, serta dapat membahayakan sendi-sendi kehidupan masyarakat dalam arti seluas-luasnya.

Yustisia Vol.1 No.1 Januari - April 2012
Dari latar belakang yang telah diuraikan di atas, persoalan yang muncul adalah bagaimana gambaran problematika perlindungan hak cipta dan solusi dalam mengatasinya di Indonesia?

\section{B. Problematika Perlindungan Hak Cipta di Indonesia}

Pada masa lalu bisnis internasional hanya dalam bentuk export - import dan penanaman modal. Kini transaksi menjadi beraneka ragam dan rumit seperti kontrak pembuatan barang, waralaba, imbal beli, "turnkey project," alih teknologi, aliansi strategis internasional, aktivitas financial, dan lain-lain, (S. Tamer Cavusgil: 1993:83-86, Jaqnes Delors:1995: 723) . Globalisasi menyebabkan berkembangnya saling ketergantungan pelakupelaku ekonomi dunia. Manufaktur, perdagangan, investasi melewati batasbatas negara. meningkatkan intensitas persaingan. gejala ini dipercepat oleh kemajuan komunikasi dan tran-sportasi teknologi. (Richard C. Breeden:1993:514 ) . Manakala ekonomi menjadi terintegrasi, harmonisasi hukum mengikutinya. Terbentuknya WTO (World Trade Organization) telah didahului atau diikuti oleh terbentuknya blok-blok ekonomi regional seperti Problematika Perlindungan... 72 
Masyarakat Eropah, NAFTA, AFTA dan APEC. Tidak ada kontradiksi antara regionalisasi dan globalisasi perdagangan. Sebaliknya, integrasi ekonomi global mengharuskan terciptanya blok-blok perdagangan baru

( Bary Hufbauer:1995:108). Bergabung dengan WTO dan kerjasama ekonomi regional berarti mengembangkan institusi yang demokratis, memperbaharui mekanisme pasar, dan memfungsikan sistim hukum. (Paul Demaret:1995:123-171,Mary E.Footer:1995:464-466).

Prinsip-prinsip "Most Favoured - Nation." "Transparency,", "National Treatment..' "Non Dicrimination" menjadi dasar WTO dan blok ekonomi regional, (Carl J Green:1995:. 729, Gerard de Graaf and Matthew King: 1995:452) globalisasi ekonomi menimbulkan akibat yang besar sekali pada bidang hukum. Globalisasi ekonomi juga menyebabkan terjadinya globalisasi hukum, globalisasi hukum tersebut tidak hanya didasarkan kesepakatan internasional antar bangsa, tetapi juga pemahaman tradisi hukum dan budaya antara Barat dan Timur. Globalisasi hukum terjadi melalui usaha-usaha standarisasi hukum. antara lain melalui perjanjianperjanjian internasional. (Stephen Zamora:1993: 406433). General Agreement on

Yustisia Vol.1 No.1 Januari - April 2012
Tariff and Trade (GATT) misalnya, mencantumkan bebarapa ketentuan yang harus dipenuhi oleh negaranegara anggota berkaitan dengan penanaman modal, hak milik intelektual, dan jasa. Prinsip-prinsip "NonDiscrimination," "Most Favoured Nation," "National Treatment," "Transparency" kemudian menjadi substansi peraturan-peraturan nasional negara-negara anggota. ( Micheal A Geist:1995:714716,Denine ManningCabral:1995: 1171-1199)

Prinsip hukum Hak Cipta, atau konvensikonvensi internasional terkait dengan hak kekayaan intelektual selalu bermotifkan ekonomi. Tidak mengherankan apabila pengusung konvensi internasional adalah negaranegara maju yang menghasilkan komoditas yang memiliki hak cipta seperti perangkat lunak komputer, film, inovasi teknologi dan sebagainya. Untuk itulah negara-negara maju seringkali menekan negara-negara berkembang agar memberlakukan hukum Hak Cipta di negaranya guna melindungi komoditas ekspornya.

Keadaan ini $\begin{array}{r}\text { sangat } \\ \text { berbeda dengan } \\ \text { negara } \\ \text { seperti }\end{array}$
$\begin{aligned} & \text { Indonesia. } \\ & \text { masyarakat }\end{aligned}$
Kebanyakan
Problematika Perlindungan... 73


masyarakat komunal yang sering mengesampingkan Hak Cipta. Bagi mereka, bisa menghasilkan suatu ciptaan yang berguna untuk masyarakat saja sudah lebih dari cukup. Dalam suatu penelitian di daerah Boyolali dan Surakarta yang dilakukan oleh Absori (Riswandi dan Syamsudin, 2004: 202) ditemukan bahwa kebanyakan pengrajin tembaga di sana tidak mempermasalahkan corak dan model tembaga mereka ditiru oleh pihak lain. Mereka juga tidak menuntut para penirunya ke lembaga pengadilan. Walau mereka sadar sepenuhnya peniruan terhadap karya mereka akan merugikan secara ekonomis.

Masyarakat adat di
Indonesia juga tidak
mengenal hukum hak cipta.
Tidak berlebihan bila
dikatakan hukum hak cipta
ini tidak mengakar dalam
kebudayaan Indonesia.
Keadaan inilah yang
mendasari adanya dilema
dalam penegakan hukum hak
cipta di Indonesia, walaupun
Indonesia merupakan salah
satu negara yang
menandatangani persetujuan
internasional mengenai hak
cipta seperti TRIPs (Trade
Related Aspects of
Intellectual Property Rights)
umpamanya. Perjanjian
TRIPs sangat mengikat
pemerintah Indonesia untuk
melindungi hak cipta dari
Vol.1 No.1 Januari-April 2012

mana saja asal penciptanya, namun dalam implementasinya masyarakat belum bisa menghormati hak cipta karena kebiasaan yang berkembang di masyarakat masih komunal.

Salah satu refleksi masyarakat yang tidak begitu peduli dengan hak cipta adalah kecenderungan masyarakat yang sering membeli barang tiruan, bajakan atau barang-barang yang tidak orisinil. Masyarakat sebagai konsumen tidak peduli apakah barang yang mereka beli itu termasuk barang palsu, bajakan, ada hak ciptanya atau tidak, yang terpenting bagi mereka adalah bisa mendapatkan barang-barang dengan harga terjangkau. Tak terkecuali buku, perangkat lunak maupun bahan-bahan perpustakaan lainnya.

Perubahan kualifikasi dari tindak pidana aduan dalam UU Hak Cipta sebelumnya menjadi tindak pidana biasa dalam UU Hak Cipta tebaru ternyata mendorong aparat kepolisian untuk bertindak proaktif. Hal ini dibuktikan dengan adanya razia besar-besaran terhadap rental VCD bajakan, toko komputer dan sebagian penjual VCD bajakan. Akan tetapi tindakan yang telah dilakukan POLRI sendiri ternyata hanya memberikan

Problematika Perlindungan... 74 
sebuah rekasi kejut yang tidak bertahan lama, terbukti dengan maraknya kembali penjualan produk-produk bajakan yang hanya berselang beberapa minggu setelah diadakannya razia. Kenyataan ini memberikan kesan bahwa pelaku tindak pidana pembajakan di Indonesia telah sedemikian bebasnya dalam melakukan aksinya.Hal ini dapat dikatakan bahwa ketentuan dalam pasal 72 UU No.19 Tahun 2002 tentang Hak Cipta yang memberikan ketentuan sanksi yang lebih berat dari UU Hak Cipta sebelumnya, pada kenyataanya belum berhasil menimbulkan efek penjeraan sebagaimana yang diharapkan oleh pembuat UndangUndang.

\begin{tabular}{lr}
\multicolumn{1}{c}{ Dalam memberikan } \\
perlindungan hak cipta \\
mengalami $r$ beberapa \\
kesulitan terkait untuk \\
mengatasi banyaknya kasus \\
pelanggaran hak cipta, yang \\
mana tidak lepas dari adanya \\
2 (dua) faktor utama : ( \\
William R Cornish: 1999)
\end{tabular}

1. Faktor ekonomi, yaitu karena mahalnya harga produk barang legal, sehingga mendorong

masyarakat mencari barang yang labih murah harganya;

2. Faktor kesadaran hukum masyarakat yang relatif rendah sehingga kurang menghargai sebuah hasil karya cipta.

Beberapa problematika perlindungan hak cipta di Indonesia adalah sebagaimana tergambar berikut ini.

1. Pandangan Islam terhadap Hak Cipta

Pemikir Islam Imam alQaraafi adalah tokoh Islam pertama yang membahas masalah hak cipta. Dalam kitabnya yang berjudul alIjtihadat, Imam al-Qaraafi berpendapat bahwa hasil karya cipta (hak cipta) tidak boleh diperjual belikan karena hak tersebut tidak bisa dipisahkan dalam sumber aslinya.

Namun demikian pendapatnya ini dibantah oleh Fathi al-Daraini yang berpendapat bahwa hak cipta merupakan sesuatu yang dapat diperjual belikan, karena adanya pemisahan dari pemiliknya. Dalam hak cipta ia mengatakan harus ada standar orisinalitas yang membuktikan keaslian ciptaan tersebut. (Masfuk Zuhdi:1988: 85-89 ). Karena hak cipta tersebut hak milik pribadi, maka agama melarang orang yang tidak berhak (bukan pemilik hak cipta), baik untuk 
kepentingan pribadi maupun untuk kepentingan bisnis.

Demikian pula untuk menterjemahkan ke dalam bahasa lain dan sebagainya dilarang. Kecuali dengan izin penulisnya atau penerbit yang diberi hak untuk menerbitkannya. Perbuatan, mencetak dan sebagainya terhadap karya tulis seseorang tanpa izin penulis sebagai hak cipta, atau ahli warisnya yang sah, atau penerbit yang diberi wewenang oleh penulisnya adalah perbuatan tidak etis dan dilarang oleh Islam. Sebab perbuatan semacam itu bisa termasuk kategori pencurian. Kalau dilakukan dengan sembunyi-sembunyi dan diambil dari tempat penyimpanan karya tulis tersebut atau disebut sebagai perampasan, kalau dilakukan dengan terang-terangan dan diikuti dengan kekerasan yang disebut pencopetan, dan kalau dilakukan secara sembunyi-sembunyi dan di luar tempat penyimpanannya yang semestinya dikatakan sebagai penggelapan.

Adapun dalil-dalil syar'i yang dapat dijadikan dasar melarang pelanggaran hak cipta dengan perbuatanperbuatan tersebut di atas antara lain sebagai berikut. Artinya:" janganlah sebagian kamu memakan harta sebagaian yang lain dengan cara bakhil." Islam menghormati hak milik pribadi, tetapi hak milik pribadi itu bersifat sosial, karena hak milik pribadi pada hakikatnya adalah hak Allah SWT yang diamanatkan kepada orang yang kebetulam memilikinya, oleh karenanya karya tulis itupun harus bisa dimanfaatkan oleh umat, tidak boleh dirusak, disembunyikan oleh pemiliknya. Penulis atau penerbit tidak dilarang untuk mencantumkan kata-kata "dilarang mengutip dan/ atau memperbanyak dalam bentuk apapun bila tidak ada izin tertulis/ penerbit". Sebab pernyataan tersebut dilakukan hanya untuk bertujuan melindungi hak ciptanya dari usaha pembajakan dan sebagainya.(lampiran Fatwa MUI Nomor:1/MUNAS VII/MUI/15/2005 )

Setelah dipahami satu persatu tentang konsep hak milik dalam pandangan hukum positif dan hukum Islam, dibuat sebuah perbandingan(Syafrinaldi: 2008:214-215):

a. Dunia Islam mengenal hak milik dalam sebuah batasan tertentu, yang tidak sama pemahamannya dengan pemikiran hak milik dari kalangan kaum kapitalis .

b. Islam hanya mengakui hak milik mutlak hanya milik Allah Swt,dan tidak bisa menerima teori kepemilikan ekslusif dari faham kapitalis, yang pada

Problematika Perlindungan... 76 
akhirnya bertentangan dengan sistem sosial Islam

c. Islam melihat harta sebagai bagian hak milik yang memiliki nilai dan manfaat seperti juga yang dikemukakan oleh teori hak milik dari dunia barat, hanya saja tidak selamanya hak milik tersebut berorentasi pada nilai dan manfaat material semata, tapi juga dibutuhkan dalam segi sosial.

d. Proses kepemilikan hak dalam Islam pada dasarnya melekat dengan sendirinya tanpa ada sebuah proses, sedangkan dalam pandangan hukum positif, hak milik baru akan melekat pada pemiliknya apabila ada sebuah proses yang dalam hal ini proses pendaftaran kepada lembaga yang berwenang. Setelah itu baru hak milik mendapat sebuah pengakuan dan perlindungan.

e. Hak milik dalam Islam mengacu pada ketentuan syara' sedangkan hak milik dalam hukum positif bersandar kepada sebuah produk Undang-undang.

f. Dalam pandangan hukum positif, kemajuan sebuah bangsa dilihat dari frekuensi rakyatnya dalam melakukan sebuah penemuan dan karya-karya inteletualnya, sedangkan dalam Islam yang dapat dlihat dari sejarah, kemajuan suatu bangsa

Yustisia Vol.1 No.1 Januari - April 2012 tidak hanya terletak dari banyaknya penemu dalam menemukan karyakaryanya, tetapi yang paling penting dan pokok menciptakan kondisi yang kondusif untuk menunjang dan mendukung terlahirnya embrio baru dari hasil karya pemikiran manusia.

g. Pada dasarnya Islam tidak mengenal perlindungan hak milik Immaterial, ketika hak milik yang abstrak tadi terlahir menjadi sebuah hak milik yang kongkrit atau hasil dari perwujudannya, baru Islam mempunyai suatu perlindungan hukum yang pada akhirnya nanti disandarkan kepada hukum hak milik.

h. Islam memandang dalam penggunaan intelektual seseorang hanya sebatas penyebarluasan ilmu pengetahuan kepada umat manusia sebagai suatu kewajiban yang tidak berorentasi dengan nilai.

2. Pandangan Masyarakat Tentang Hak Cipta

Pandangan masyarakat pada umumnya sampai sekarang berbeda dengan pandangan UU Hak Cipta, masyarakat masih memandang hak cipta sebagai milik bersama (Res Communis) sedangkan Undang-Undang memandang

Problematika Perlindungan... 77 
hak cipta sebagai milik perseorangan (res nullius). Perbedaan pandangan ini merupakan salah satu penyebab maraknya pelanggaran hak cipta di masyarakat. Masyarakat Indonesia sebenarnya sudah lama mengenal hak cipta sejak zaman nenek moyang sebelum datangnya penjajah. Hak cipta yang berlaku berdasarkan hukum adat karena masyarakat Indonesia waktu itu termasuk masyarakat hukum adat. Menurut Van Vollenhoven dari hasil penelitiannya di Indonesia terdapat 19 masyarakat hukum adat.

Pada waktu zaman Belanda hak cipta yang diberlakukan di Hindia Belanda adalah Auteurswet 1912 yang berlaku sampai Indonesia Merdeka dan mempunyai UU Hak Cipta sendiri yaitu UU N0.6 Tahun 1982 tentang Hak Cipta. Jadi setelah merdeka 37 tahun baru mempunyai UU Hak Cipta Nasional. Meskipun demikian apabila dipelajari isinya antara Auteurswet 1912 dengan UU Hak Cipta dilatarbelakangi alam pikiran Barat di mana bersifat Universal. Karena sebagai milik perorangan maka orang lain tidak boleh meniru ciptaan kecuali dengan meminta izin terlebih dahulu dari pencipta.

Yustisia Vol.1 No.1 Januari - April 2012
Berbeda dengan masyarakat Indonesia yang sampai sekarang pandangannya masih dilatarbelakangi oleh pemikiran masyarakat hukum adat yaitu kebersamaan, dengan memandang hak cipta sebagai milik bersama. Sebuah ciptaan yang dibuat oleh seseorang kapan saja, di mana saja, dan diapakan saja tidak ada masalah. Bahkan ada seniman patung dari Bali merasa tidak keberatan ciptaannya ditiru dan merasa bangga serta menganggap orang yang meniru tersebut sebagai murid-muridnya. Demikian pula dengan penjualan patung tiruan dipandang bahwa rezeki orang sudah diatur sendirisendiri oleh Yang Maha Kuasa.

Perbedaan pandangan tersebut, membawa akibat suatu perbuatan sudah merupakan kejahatan hak cipta dari sudut UU Hak Cipta, tetapi masyarakat memandang perbuatan tersebut bukan sebagai kejahatan perlu dihukum.

Pandangan masyarakat yang masih memandang hak cipta sebagai milik bersama memang menghambat pelaksanaan hukum tertulis tentang hak cipta karena pandangannya bertolak belakang. Jalan keluarnya untuk itu harus mengubah pandangan masyarakat dari Problematika Perlindungan... 78 
res communis menjadi res nullius untuk hak cipta dan HKI (Hak Kekayaan Intelektual ) pada umumnya, namun bukan persoalan yang mudah karena masyarakat Indonesia jumlahnya ratusan juta orang. Selain harus ada kemauan politik dari pemerintah, juga adanya kemauan dari masyarakat kita sendiri, bagaimana kesadaran hukum masyarakat tentang hak cipta dapat di wujudkan.(Gatot

Supramono:2010)

3. Masih

Kurangnya

Memasyarakatkan

Undang-Undang Hak

\section{Cipta}

Sejak Indonesia merdeka tahun 1945 negara Indonesia menganut sistem hukum tertulis. Semua peraturan hukum yang berlaku dituangkan dalam bentuk tertulis sehingga semua warga masyarakat lebih mudah mengetahui dan memahaminya. Meskipun demikian masih banyak masyarakat yang tidak mengetahui dan memahami hukum tertulisnya.

Banyak pelanggaran hak cipta di negara Indonesia juga disebabkan UU Hak Cipta sebagai hukum tertulis masih kurang dipahami masyarakat. Sudah lama negara Indonesia mempunyai UU Hak Cipta tetapi sebagian besar masyarakat masih banyak

Yustisia Vol.1 No.1 Januari - April 2012 yang kurang memahami termasuk kalangan petugas hukum yaitu polisi, jaksa dan hakim, kemudian pedagang, pengusaha, dan mahasiswa.

Kurang

memasyaratkannya UU Hak Cipta diduga disebabkan dipengaruhi oleh faktorfaktor antara lain peraturan tertulis dibuat oleh sekelompok orang, masyarakat kurang berminat membaca peraturan dan minimnya penyuluhan hukum.

Mengenai faktor yang pertama, peraturan tertulis berupa Undang-Undang pada kenyataannya di buat oleh sekelompok orang yaitu Dewan Perwakilan Rakyat dan Presiden. Sekelompok orang tersebut bertugas mewakili kepentingan rakyat, akan tetapi kepentingannya itu belum tentu benar-benar mewakili rakyat. Sampai sekarang masih banyak rakyat yang tidak tahu ketika para wakilnya membuat UndangUndang.

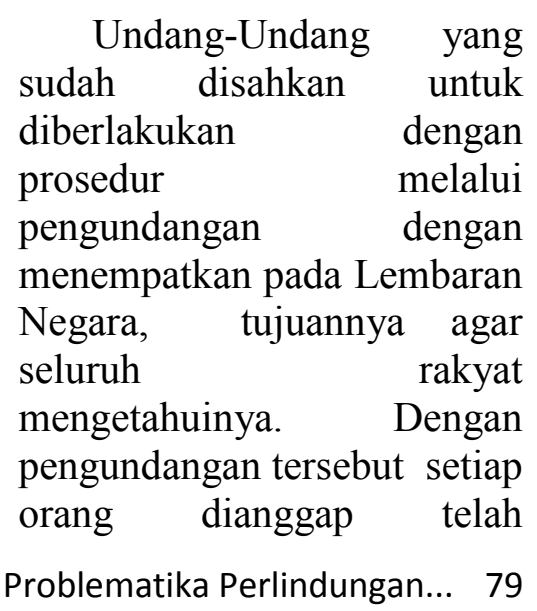


mengetahui adanya UndangUndang yang baru yang langsung diberlakukan. Padahal kenyataannya tidak demikian sebagian besar masyarakat kita belum banyak mengetahuinya.

Faktor yang kedua, faktor ini seperti melengkapi faktor pertama di atas. Sudah tidak mengetahui ada peraturan baru yang dilahirkan, ditambah masyarakat kurang berminat membaca peraturan. Sampai sekarang minat membaca masyarakat masih kurang terlebih lagi minat untuk membaca peraturan.

Rendahnya minat membaca dipengaruhi oleh sejarah masa lalu ketika masih berlaku hukum adat sebelum negara Indonesia dijajah oleh bangsa lain. Sebagaimana diketahui bahwa hukum adat kaidah hukum yang tidak tertulis. Meskipun peraturannya tidak tertulis namun hukum adat ditaati dan dipatuhi oleh masyarakatnya. Masyarakat mengetahui aturan hukum adat bukan dari membaca melainkan dari melihat dan bertanya kepada orang lain dan mengalaminya sendiri.

$\begin{array}{lrr}\text { Sewaktu dijajah } & \begin{array}{r}\text { negara } \\ \text { oleh }\end{array} \\ \text { Indonesia hukum yang } \\ \text { Belanda, hum } \\ \text { diberlakukan adalah hukum } \\ \text { yang berlaku dari negaranya. } \\ \text { Sistem hukum yang berlaku } \\ \text { di negara Belanda adalah }\end{array}$

Yustisia Vol.1 No.1 Januari - April 2012 sistem hukum tertulis. Pada waktu itu Belanda tidak memaksa memberlakukan hukum tertulisnya kepada masyarakat Indonesia, dengan mendasarkan Pasal 131 jo Pasal 163 IS orang Bumi Putra tetap berlaku pada hukum adatnya. Meskipun demikian masyarakat kita diperbolehkan menundukkan diri kepada hukum Belanda jika hendak menggunakannya.

Setelah Indonesia merdeka sistem hukum yang dianut adalah sistem hukum tertulis, dengan diawali dibentuknya UUD 1945 sampai kepada peraturanperaturan pelaksanaannya dibuat secara tertulis. Meskipun hukumnya sudah dibuat secara tertulis namun pengaruh sejarah masa lalu masih kuat sekali sampai sekarang. Sikap nenek moyang di zaman hukum tidak tertulis masih sulit untuk dilepaskan dari masyarakat Indonesia walaupun zaman sudah berubah.

Bagi para pengusaha dan pedagang yang dalam aktivitas kesehariannya berhubungan dengan masalah hak cipta tentunya tidak dapat bersikap demikian. Mereka harus menyadari apabila usahanya menyangkut tentang ciptaan seseorang jelas ada hak ciptanya. Oleh karena itu, tidak ada ruginya

Problematika Perlindungan... 80 
apabila mereka mengetahui peraturannya, sehingga dapat menghindari adanya pelanggaran hak cipta.

Faktor yang ketiga, yaitu minimnya penyuluhan hukum kepada masyarakat. Pada dasarnya hukum tertulis yang sudah disahkannya tidak cukup hanya dengan mengundangkan di dalam Lembaran Negara dan masyarakat kemudian dianggap telah mengetahuinya, hal tersebut karena asas fiksi hukum, yang semua orang dianggap tahu tentang hukum tanpa pandang bulu. Hal ini terkesan menutup mata, telinga kalau warga negara Indonesia yang terdiri atas berbagai pulau, dengan berbagai kendala yang dihadapi untuk bias mengakses perkembangan hukum baik melalui media cetak maupun elektronik dikarenakan beberapa hal seperti misalnya factor ekonomi, social ,ilmu pengetahuan dan teknologi. Agar masyarakat dapat mengetahui dan memahami hukumnya perlu disosialisasikan. Terkadang dijumpai sebuah UndangUndang yang telah diundangkan, salinannya dikirimkan ke berbagai instansi pemerintah dan ada pula yang dimuat secara berlanjut di sebuah surat kabar harian.

Yustisia Vol.1 No.1 Januari - April 2012
Meskipun demikian, Undang-Undang yang telah sampai ke masyarakat belum tentu dibaca dengan baik karena seperti deketahui minat membaca peraturan masih rendah. Kalaupun masyarakat membaca Undang-Undang belum tentu mereka dapat memahami peraturannya dengan benar.

Selama ini penyuluhan
hukum yang dilakukan
pemerintah memang sudah
berjalan namun frekuensinya
masih minim diduga mungkin
dananya masih terbatas.
Pihak pemerintah yang
berwenang melaksanakan
penyuluhan hukum adalah
Departemen Hukum dan
HAM. Dahulu sewaktu
pengadilan administratif masih di bawah Departemen Kehakiman setiap tahun melakukan penyuluhan hukum ke masyarakat bertempat di kecamatan atau kelurahan/desa. Penyuluhan hukum dilakukan enam kali dalam satu tahun dan pada umumnya yang disuluhkan berbagai materi UndangUndang, tetapi masih jarang sekali penyuluhan tentang materi HKI termasuk Hak Cipta.

Minimnya penyuluhan hukum tersebut berpengaruh kepada masyarakat yang kurang memahami hak cipta. Hak cipta hanya dipahami sejumlah orang-orang tertentu

Problematika Perlindungan... 81 
saja yang tugasnya di bidang Hak Cipta atau mereka yang mendalami hukum tersebut. Oleh karena itu yang tampak adalah UU Hak Cipta dibuat baru sampai lapisan masyarakat tertentu dan belum sampai ke seluruh lapisan masyarakat.

4. Pembeli tidak Pernah Dipersoalkan

Dalam penindakan
pelanggaran hak cipta
terutama penggrebekan atau
penangkapan pada waktu
dilakukan di lapangan sasaran
petugas hanya sepihak yaitu
ditujukan kepada pembajak
dan pedagang barang bajakan
hak cipta, sedangkan kepada
masyarakat yang membeli
barang bajakan tersebut tidak
pernah dilakukan penindakan.
Perlunya pemikiran bahwa
pembajak dan penjual barang
bajakan ditindak, maka tidak
ada yang jual tentu dengan
sendirinya tidak ada
pembelinya. Selama ini,
pembeli barang bajakan tidak
dilakukan penindakan karena
mereka tidak dapat dikenakan
ketentuan UU Hak Cipta.
Meskipun demikian
perbuatan mereka sebenarnya
tetap sebagai kejahatan,
karena dapat dikenakan
kejahatan penadahan
berdasarkan Pasal 480 KUHP
sebagai berikut:

Diancam dengan pidana penjara paling lama empat tahun atau pidana denda

Yustisia Vol.1 No.1 Januari - April 2012 paling banyak sembilan ratus rupiah :

(1) Barangsiapa membeli, menyewa, menukar, menarik keuntungan, menjual, menyewakan, menukarkan, menggadaikan, mengangkut, menyimpan atau menyembunyikan sesuatu barang yang diketahui atau patut disangkanya bahwa barang tersebut diperoleh dari kejahatan;

(2) Barang siapa menarik keuntungan dari hasil sesuatu barang yang diketahuinya atau patut disangkanya bahwa barang tersebut diperoleh dari kejahatan.

Jadi pembeli barang bajakan hak cipta tetap dapat dipidana dengan ketentuan Pasal 480 KUHP Ayat (1), pasal tersebut karena perbuatannya membeli barang hasil kejahatan.

Setelah mengetahui bahwa pembeli barang bajakan tersebut dapat dipidana, apakah dalam melaksanakan penanggulangan pelanggaran hak cipta akan tetap dibiarkan begitu saja, hal ini bergantung kepada kemauan penyidik untuk menindaknya. Seharusnya memang para pembeli barang bajakan ditanggap dan diadili tanpa pandang bulu, karena perbuatan mereka merupakan Problematika Perlindungan... 82 
salah satu faktor yang merangsang para pembajak baru maupun yang sudah jadi terpidana mengulangi perbuatannya lagi.

Apabila

dalam penanggulangan pelanggaran hak cipta dilakukan penindakan terhadap pembajak dan pedagang barang hasil bajakan di satu pihak, pembeli juga ditindak, maka yang terjadi barang tersebut tidak ada pihak yang memproduksi dan memperdagangkan, dan juga tidak ada pihak pembelinya.

\section{Kesadaran Hukum Masyarakat}

Persoalan kesadaran hukum masyarakat lebih tertuju kepada kesadaran hukum terhadap hukum tertulis, persoalan ini terlihat pada kelancaran pelaksanaannya hukumnya. Apabila di dalam pelaksanaan hukum tertulis banyak warga masyarakat tidak mengindahkan atau tidak mematuhi kaidah hukumnya sehingga banyak terjadinya penyimpangan hukum maka dapat disimpulkan kesadaran hukum masyarakat rendah.

\section{UU Hak Cipta} merupakan salah satu hukum tertulis dan Undang-Undang tersebut sudah lama ada, namun dalam perjalan pelaksanaan UU Hak Cipta selama ini banyak

Yustisia Vol.1 No.1 Januari - April 2012 penyimpangan-

penyimpangan terhadap kaidah - kaidahnya berupa pelanggaran bauk yang pelakunya diadili maupun yang tidak diadili.

Dari Badan Reserse Kriminal Polri, untuk data pelanggaran hak cipta tergolong sangat tinnggi, untuk tahun 2004 sebanyak 209 kasus, tahun 2005 sebanyak 506 kasus dan tahun 2006 sampai mei sebanyak 987 kasus. Jumlah kasus hak cipta tersebut dibandingkan dengan kasuskasus HKI lainnya yang jumlahnya sangat sedikit

Banyak pelanggaran hak cipta baik yang menjadi perkara dan yang lain tidak menjadi perkara dapat menggambarkan bahwa tingkat kesadaran hukum masyarakat di bidang hak cipta masih tergolong rendah. Rendahnya tingkat kesadaran hukum masyarakat tersebut disebabkan sebagian besar masyarakat masih banyak yang belum mengenal dan memahami UU Hak Cipta. Undang-Undang tersebut dibuat sebagai peraturan nasional tetapi hanya dikenal oleh warga masyarakat. Sebagaimana yang pernah dibahas di atas sampai sekarang masih terjadi perbedaan antara pandangan UU Hak Cipta dengan pandangan masyarakat. Undang-Undang memandang Problematika Perlindungan... 83 


\begin{abstract}
hak cipta sebagai perseorangan, sedangkan masyarakat memandang hak cipta sebagai milik bersama. Perbedaan pandangan tersebut mempunyai pengaruh yang sangat besar terhadap tingkat kesadaran hukum masyarakat.
\end{abstract}

Sebagaimana pendapat Friedman, yang menyatakan bahwa tegaknya peraturanperaturan hukum bergantung budaya hukum masyarakatnya. Budaya hukum masyarakat bergantung budaya hukum anggota-anggotanya yang dipengaruhi oleh latar belakang pendidikan, lingkungan budaya, posisi atau kedudukan, bahkan kepentingan-kepentingan.

Dalam menghadapi hal yang demikian itu perlu "check and balance" dalam bernegara. "Check and balance" hanya dapat dicapai dengan parlemen yang kuat, pengadilan yang mandiri, dan partisipasi masyarakat melalui lembaga-lembaganya. Dalam hal tersebut, khususnya dalam masalah pengawasan dan Law Enforcement, dua hal yang merupakan komponen yang tak terpisahkan dari sistim rule of law. Tidak akan ada law enforcement kalau tidak ada sistim pengawasan dan tidak akan ada rule of law kalau tidak ada law enforcement yang memadai.

Yustisia Vol.1 No.1 Januari - April 2012
Apabila
masyarakat
masih
memandang hak cipta sebagai
milik bersama dan di lain
pihak masyarakat tidak
memahami bahwa membeli
barang bajakan hak cipta
sebagai sebuah kejahatan,
maka sikap yang demikian
akan berpengaruh
menyuburkan pembajakan
hak cipta di negara kita. Oleh
karena itu diperlukan usaha
untuk meningkatkan kesadarn hukum terutama di bidang hak cipta sebagai milik bersama menjadi sebagai milik perseorangan dengan melakukan penyuluihan hukum atau ceramah-ceramah tentang hak cipta sekaligus tentang HKI lainnya ke tengah-tengah masyarakat selain itu juga dirasa penting untuk mengkalim para pembajak dengan berbagai poster yang isinya cinta indonesia cinta karya sendiri dan hormati karya orang lain serta stop pembajakan. Pemerintah melalui Departemen Hukum dan HAM perlu memberi perhatian serius dengan menyiapkan tenaga dan didukung dengan dana yang cukup untuk itu sehingga penyuluhan hukum dapat berjalan dengan lancar. Penyuluhan dapat dilakukan dalam kurun waktu tertentu dengan memperhatikan masyarakat dalam memahami hak cipta. Pemahaman hak cipta ini perlu terus digalakkan oleh pemerintah

Problematika Perlindungan... 84 
dan penegak hukum dengan melakukan kerjasama dengan berbagai lembaga pendidikan, perguruan tinggi, juga para pengusaha dan tokoh - tokoh masyarakat, karena untuk menumbuhkan kesadaran hukum atau di singkat dengan kadarkum tidak mudah sebagaimana membalik telapak tangan akan tetapi lebih pada ibaratnya menaikkan benang yang basah, sehingga kesadaran hukum masyarakat perlu ditingkatkan terus menerus.

\section{Solusi dalam Mengatasi Problematika Perlindungan Hak Cipta di Indonesia}

Dampak pelanggaran hak cipta ini disamping akan merusak tatanan masyarakat pada umumnya, juga mengkibatkan lesunya gairah untuk berkarya di bidang ilmu pengetahuan, seni dan sastra. Dampak lainnya adalah berkurangnya penghasilan negara berupa pajak penghasilan yang seharusnya di bayar oleh pemegang hak cipta (Insan Budi Maulana, Ridwan Khairandy, Nurjihad: 2000:189).

Problematika

pelanggaran hak cipta di bidang lagu atau musik ini, dimulai tahun 1990an yang terlihat dari banyak beredar kaset, compact disc ataupun video Compact Disc yang berisi penyanyi dari dalam dan luar negeri yang dijual sebagai hasil kopi bajakan. Kemudian persoalan ini memudar karena para penyanyi, pencipta lagu dan para produser ramai-ramai melakukan protes dan mengancam menggugat secara hukum bagi siapapun yang memperbanyak kaset, compact disc ataupun video Compact Disc lagu atau musik secara ile compact disc ataupun video Compact Disc lagu atau musik secara illegal. Namun, langkah para seniman musik memberantas kegiatan illegal itu hanya menghentikan sesaat masalah pelanggaran hak cipta. Buktinya, akhir-akhir ini kembali beredar kaset, compact disc ataupun video Compact Disc lagu atau musik bajakan. Bahkan, tidak sulit menemukan pedagang kaki lima di pinggir jalan menawarkan kaset-kaset, compact disc ataupun video Compact Disc lagu atau musik bajakan yang sudah pasti harganya jauh lebih murah dibandingkan dengan harga toko. Bukan hanya itu, pembajakan juga bertambah dengan munculnya, compact disc ataupun video Compact Disc,maupun Digital Video Disc, lagu dan musik bajakan. Di perkirakan sekitar 98\% kaset, compact disc ataupun video Compact Disc lagu atau musik yang beredar di Indonesia adalah produk bajakan.

(http://www.Tempo.co.id, Error! Hyperlink reference not

Problematika Perlindungan... 85 
valid. online $\% 20 \% 20$

http://www tempo co id:

2002)

Oleh karena itu penting kiranya dilakukan beberapa cara untuk mengatasi problem/ masalah-masalah yang muncul dalam perlindungan hak cipta di Indonesia, hal tersebut diantaranya adalah sebagai berikut :

1. Sosialisasi terhadap pentingnya penghormatan atas Hak kekayaan intelektual pada umumnya dan hak cipta pada khususnya, melalui pendidikan masyarakat luas terutama generasi mudanya pada tahap sedini mungkin sehingga bisa mengetahui betapa penting dan berartinya sebuah karya cipta;

2. Peningkatan kesadaran hukum bagi masyarakat

3. Peningkatan ekonomi masyarakat dengan mendorong terciptanya karya-karya intelektual /HKI.

4. Dukungan dari pemerintah dalam bentuk peran serta menyediakan perangkat perundang - undangan. Dalam hal ini hak cipta telah diatur dalam UU No 19 Tahun 2002 tentang Hak Cipta yang merupakan pengganti dari Undang-Undang Nomor

Yustisia Vol.1 No.1 Januari - April 2012
12 Tahun 1997 tentang Hak Cipta, maka dari itu substansi dalam UndangUndang tersebut kiranya perlu benar-benar dilaksanakan dan ditegakkan sehingga bagi pelanggar hak cipta harus dirazia dan ditangkap sesuai peraturan perundang-undangan yang berlaku;

5.Meningkatkan kualitas para penegak hukumnya melalui pendidikan supaya dapat menegakkan keadilan dan mencari kebenaran dalam menangani kasus-kasus pelanggaran Hak kekayaan intelektual pada umumnya dan pelanggaran hak cipta pada khususnya.

Dibalik usaha keras menciptakan globalisasi hukum, diantaranya dalam hukum hak cipta, menurut Erman, tidak ada jaminan bahwa hukum tersebut akan memberikan hasil yang sama di semua tempat. Hal mana dikarenakan perbedaan politik, ekonomi dan budaya. Hukum itu tidak sama dengan kuda. Orang tidak akan menamakan keledai atau zebra adalah kuda. Walau bentuknya hampir sama. Kuda adalah kuda. Hukum tidak demikian. Apa yang disebut hukum itu tergantung kepada persepsi masyarakatnya ( Erman Rajagukguk : 1997:18-19).

Problematika Perlindungan... 86 
Friedman, mengatakan bahwa tegaknya peraturan-peraturan hukum tergantung kepada budaya hukum masyarakatnya. Budaya hukum masyarakat tergantung kepada budaya hukum anggota-anggotanya yang dipengaruhi oleh latar belakang pendidikan, lingkungan budaya, posisi atau kedudukan, bahkan kepentingan-kepentingan.

Dalam menghadapi hal yang demikian itu perlu "check and balance" dalam bernegara. "check and balance" hanya bisa dicapai dengan parlemen yang kuat, pengadilan yang mandiri, dan partisipasi masyarakat melalui lembagalembaganya.

\section{Simpulan}

Problematika perlindungan hak cipta di Indonesia meliputi pandangan Islam terhadap Hak Cipta, pandangan masyarakat terhadap hak cipta, masih kurangnya memasyarakatkan Undang-Undang Hak Cipta, pembeli tidak di persoalkan, dan kesadaran hukum masyarakat. Cara untuk mengatasi problem/ masalah-masalah yang muncul dalam perlindungan hak cipta di Indonesia, hal tersebut diantaranya adalah sosialisasi terhadap pentingnya penghormatan hak cipta, peningkatan kesadaran hukum bagi masyarakat, peningkatan ekonomi masyarakat, dukungan pemerintah dalam UndangUndang Hak Cipta, dan meningkatkan kualitas para penegak hukumnya melalui pendidikan supaya dapat menegakkan keadilan dan mencari kebenaran dalam menangani kasus-kasus pelanggaran pelanggaran hak cipta pada khususnya. 


\section{Daftar Pustaka}

Bary Hufbauer. 1995. "International Trade Organizations and Economies in Transition : A Glimpse of the Twenty-First Century," Law \& Policy in International Business, vol. 26.

Budi Agus Riswandi \& M. Syamsudin. 2004. Hak Kekayaan Intelektual dan Budaya Hukum. Jakarta: PT Raja Grafindo

Carl J Green. 1995. "APEC and Trans-Pasific Dispute Management, "Law \& Policy in International Business," vol. 26

Denine Manning-Cabral. 1995. "The Eminent Death of the Calvo Clause and the Rebirth of the Calvo Principle : Equality of Foreign and National Investors," Law \& Policy in International Business vol. 26

Eddy Damian. 2009. Hukum Hak Cipta. Jakarta : IKAPI,PT Alumni. 2004. Hukum Hak Cipta Undang-Undang Hak Cipta Nomor 19 Tahun. Bandung: PT Alumni

Endang P. 2005. "Perkembangan Hukum Intellectual Property Rights. Bogor: Ghalia Indonesia.

Erman Rajagukguk. 1997. "Peranan Hukum dalam Pembangunan pada Era Globalisasi: Implikasinya bagi Pendidikan Hukum di Indonesia," Pidato Pengukuhan Guru Besar di ucapkan pada upacara penerimaan guru besar bidang hukum di Fakultas Hukum Universitas Indonesia, Jakarta 4 Januari.

Gatot Supramono. 2010. Hak Cipta dan Aspek-Aspek Hukumnya. Jakarta: PT Rineka Cipta

Gerard de Graaf and Matthew King. 1995. "Towards a More Global Government Procurement Market: The Expansion of the GATT Government Procurement Agreement in the Context of the Uruguay Round," The International Lawyer, vol. 29, No. 2

Insan Budi Maulana, Ridwan Khairandy, Nurjihad. 2000. Kapita Selekta Hak Kekayaan Intelektual I. Yogyakarta-Jakarta: Pusat Stud Hukum VII Yogyakarta bekerja sama dengan yayasan Klinik HAKI Jakarta,.

Jaqnes Delors(1995), "The Future of Free Trade in Europe and the World," Fordham International Law Journal. Vol. 18

Keputusan Fatwa Majelis Ulama Indonesia Nomor: 1/MUNAS VII/MUI/15/2005 tentang Perlindungan Hak Kekayaan Intelektual (HKI)

Mary E.Footer. 1995. "The International Regulation of Trade in Service Following Completion of the Uruguay Round," The International Lawyer, vol. 29 No. 2 
Masfuk Zuhdi. 1988. Studi Islam, (Vol.III). Jakarta: Rajawali Pers

Micheal A Geist. 1995. "Toward A General Agreement on the Regulation of Foreign Direct Investment," Law \& Policy in International Business, vol. 26

Paul Demaret. 1995. "The Metamorphoses of the GATT : from the Havana Charter to the World Trade Organization," Columbia Journal of Transnational Law, vol 34

Richard C. Breeden. 1993. "The globalization of Law and Business in the 1990s," Wake Forest Law Review, vol.28 No.3

S. Tamer Cavusgil. 1993. "Globalization of Markets and Its Impact on Domestic Institutions." Global Legal Studies Journal, vol 1

Syafrinaldi. 2008. "Perbandingan Hak Cipta Dalam Konsep Kapitalis Dengan Hak Milik Dalam Pandangan Islam Hukum Islam”. Vol. VIII No. 2 Desember.

Stephen Zamora. 1993. "The Americanization of Mexican Law : Non-Trade Issues in the North American Free Trade Agreement," Law \& Policy in International Business. Vol. 24

William R Cornish. 1999. Intellectual Property. FourthEdition. London: Sweet Maxwell

"Pembajakan Pekerjaan Rumah Yang Belum Tuntas(2002)," Tempo,18 Mei http://www.Tempo.co.id, Error! Hyperlink reference not valid. online $\% 20 \% 20$ http://www tempo co id.htm

Undang-Undang Nomor 19 Tahun 2002 tentang Hak Cipta

ANIS MASHDUROHATUN, SH., M.Hum.

(STAF PENGAJAR FAKULTAS HUKUM UNISSULA, SI FH UNISSULA, S2 UNDIP, Mahasiswa S3 PDIH UNS angkatan IV 2010, Sekretaris Bidang II: Keuangan dan Administrasi Umum Program S2 Ilmu Hukum UNISSULA) 